\title{
Climate-Induced Migration and Resilient Cities: a New Urban Agenda for Sustainable Development ${ }^{1}$
}

\author{
Migrações Climáticas e Cidades Resilientes: uma Nova Agenda Urbana para o \\ Desenvolvimento Sustentável
}

Diogo Andreola Serraglio ${ }^{1}$

Heline Sivini Ferreira ${ }^{2}$

Nicholas A. Robinson ${ }^{3}$

${ }^{1}$ German Development Institute/Deutsches Institut für Entwicklungspolitik (DIE), Alemanha

${ }^{2}$ Pontífícia Universidade Católica do Paraná (PUCPR) Curitiba, PR, Brasil

${ }^{3}$ Elisabeth Haub School of Law at Pace University, Estados Unidos

\begin{abstract}
The study aims at examining how climate-induced migration can contribute to the sustainable development of cities. Through the deductive approach, the linkages between climate change and human mobility are initially analyzed. Thereafter, it investigates how urban centers deal with such phenomena. It then looks into the Agenda 2030, with a special focus on the SDG 11. Despite the attempt to make cities and human settlements inclusive, safe, resilient and sustainable, this SDG does not take into account the role played by climateinduced migrants in urbanized areas. In view of this, the New Urban Agenda (UN-HABITAT) is explored: it recognizes that migrants can bring significant social, economic and cultural contributions to urban life.
\end{abstract}

Keywords: Climate-induced Migration. Resilient Cities. New Urban Agenda.
Resumo: O presente estudo propõe-se a examinar como migrações de cunho climático podem contribuir para a expansão sustentável de cidades. A partir do método dedutivo, as conexões entre mudanças climáticas e mobilidade humana são inicialmente analisadas. Em seguida, investiga-se como os centros urbanos lidam com tais fenômenos e, por fim, volta-se à Agenda 2030, com especial atenção ao ODS 11. Apesar de almejar tornar as cidades e os assentamentos urbanos inclusivos, seguros, resilientes e sustentáveis, esse ODS não considera o papel desempenhado por migrantes climáticos em áreas urbanizadas. Explora-se, diante disso, a Nova Agenda Urbana (ONU-HABITAT), que reconhece que migrantes podem trazer contribuições sociais, econômicas e culturais para a vida urbana.

Palavras-chave: Migração Climática. Cidades Resilientes. Nova Agenda Urbana.

${ }^{1}$ This paper was presented during the $16^{\text {th }}$ Annual Colloquium of the IUCN Academy of Environmental Law - The transformation of Enviromental Law and governance: Innovation, risk and resilience, which took place in July 2018 and was hosted by the University of Strathclyde, in Glasgow, Scotland.

Recebido em: 05/11/2019

Revisado em: 02/12/2019

Aprovado em: 10/12/2019 


\section{Introduction}

Forced migration has intensified due to the impacts of climate change over the past decades. Sea-level rise, droughts and desertification processes, as well as the higher incidence of extreme weather-events, are leading to the internal and/or cross-border displacement of people towards urban areas. This challenges the governance of several developing countries.

Considering that the global urban population increased from 746 million to 7.6 billion between 1950 and 2017, and given the estimate that a further 03 billion people will live in urbanized areas by 2050, cities try to cope with disorderly growth in a sustainable manner.

As urban centers can promote the inclusion of climate-induced migrants through policymaking, this study aims at examining how human mobility in the context of climate change can contribute to the sustainable development of cities.

Through the deductive method, the linkages between climate change and human mobility, as well as the outlines that allow the identification of people compelled to move due to environmental reasons, are initially analyzed. Thereafter, the impacts of global warming in urban areas are investigated: while cities are responsible for greenhouse gas (GHG) emissions into the atmosphere, they also become increasingly susceptible and unable to manage their consequences.

It then looks into the 2030 Agenda for Sustainable Development, with a special focus on the Sustainable Development Goal 11 (SDG 11). Despite the attempt to make cities and human settlements inclusive, safe, resilient and sustainable, this SDG does not take into account the role played by environmental migrants in urbanized areas. New approaches discussing the needs of this group of individuals are thus suggested.

In view of this, the New Urban Agenda, established by the United Nations Human Settlements Programme (UN-HABITAT), is explored. Although migration processes towards cities reveal a plethora of obstacles, it is recognized that migrants can bring significant social, economic and cultural contributions to urban life. 


\section{The Intensification of Migration Patterns due to Climate Change}

Issues surrounding climate change have proven to be among the most hotly debated of this century. This phenomenon accelerated due to the unrestrained emission of greenhouse gases (GHGs) into the atmosphere by anthropogenic activities in pursuit of economic growth ${ }^{2}$. From this perspective, Leal-Arcas ${ }^{3}$ highlights that the warming of the earth's surface is seen as a threat not only to humanity, but also to environmental sustainability.

The Fifth Assessment Report (AR5) of the Intergovernmental Panel on Climate Change (IPCC) attests that human activities have changed and continue to change the Earth's surface and atmospheric composition ${ }^{4}$. It is thus contended that man's interference with the environment has brought about the increase in average global temperatures between 1951 and 2010, with GHG emissions being the main driver behind the earth's surface temperature increasing between $0.5^{\circ} \mathrm{C}$ and $1.3^{\circ} \mathrm{C}$ in this period. Moreover, the average annual terrestrial warming recorded in the twentieth century has led, notably, to a reversal in the long term cooling trend in the northern hemisphere over the last 5000 years. In other words, regarding the annual average temperatures in the northern hemisphere, 1983-2012 were most likely the 30 hottest years of the last 1400 years $^{5}$.

The overloading caused by steadily increasing air pollution has intensified environmental impacts, raising problems for the international community, such as the need to regulate the situation of those forced to migrate as a result of the effects of climate change.

Human mobility due to environmental misfortunes is not without precedent in the history of humanity. The devastation of the environment

\footnotetext{
2 BRADBROOK, A.; OTTINGER, R. Energy law and sustainable development. Geneva, Switzerland: IUCN, 2003. p. 13-14.

3 LEAL-ARCAS, R. Climate change and international trade. Cheltenham, UK: Edward Elgar Publishing Limited, 2013. p. 28.

${ }^{4}$ IPCC, 2013, p. 18.

${ }^{5}$ IPCC, 2013, p. 25-26.
} 
and the incidence of natural disasters, and associated poverty, water secutiry, food and other social conflicts, have always posed a threat to the survival of mankind, leading to the migration of several human settlements ${ }^{6}$.

Myers $^{7}$ notes that the total number of people displaced by environmental degradation globally in 1995 amounted to at least 25 million people, while "traditional" refugees totaled no more than 27 million individuals in the same year. The author also points out that the situation of those forced to migrate because of environmental disasters may

[...] become one of the foremost human crises of our times. This far they have been viewed as a peripheral concern, a kind of aberration from the normal order of things. In the world of the future, they are likely to become a prominent feature of our One Earth landscape. The phenomenon is an outward manifestation of profound change - a manifestation often marked by extreme deprivation, fear and despair ${ }^{9}$.

With regard to climate change, it is estimated that the number of people relocated to escape from sea-level rise, drought and desertification, as well as from extreme weather events, will rise from 200-250 million to possibly 1 billion people by the middle of the $21^{\text {st }}$ century ${ }^{10}$. The International Organization for Migration (IOM) projected that between 100 and 200 million people will leave their homes to seek shelter in other locations due to climate change by $2100^{11}$. Still, the United Nations Environment Programme (UN Environment) anticipates that "a total of

${ }^{6}$ RAMOS, E. P. Refugees, migrants or displaced persons: an approach inspired by environmental protection and human rights. In: LEITE, José Rubens Morato (Coord.). Manual de Direito Ambiental. $1^{\text {st }}$ Ed. São Paulo: Saraiva, 2015. p. 739.

${ }^{7}$ MYERS, N. Environmental exodus: an emergent crisis in the global arena. Washington: Project of the Climate Institute, 1995. p. 20.

${ }^{8}$ See Article 1 of the 1951 Convention Relating to the Status of Refugee.

${ }^{9}$ MYERS, 1995, p. 20.

${ }^{10}$ LEAL-ARCAS, 2013, p. 28.

11 INTERNATIONAL ORGANIZATION FOR MIGRATION (IOM). Migration, environment and climate change: Assessing the evidence. Switzerland: IOM, 2009. 
4.5 billion hectares around the world - fully 35 percent of the Earth's land surface - are in various stages of desertification. These areas are home to more than 850 million people"12 13 .

According to the Internal Displacement Monitoring Centre (IDMC), the number of natural disasters related to climate change has more than doubled over the past two decades. In addition to that, an annual average of 26.4 million people were forced to move within their national borders as a result of such phenomena between 2008 and 2017. In 2017 alone, 18.8 million new individuals became internally displaced in 135 countries: "weather-related hazards triggered the vast majority, with floods accounting for 8.6 million and storms, 7.5 million. China, Philippines, Cuba and the United States were the worst affected"14.

Notwithstanding that the 1951 Convention Relating to the Status of Refugees listed circumstances giving rise to refugee status, such as race, religion, nationality, membership of a social group and political opinion, it may be argued that this definition should not be deemed to cover every situation that could be included in the definition of refuge. Scientific development ever since has resulted not only more armed conflicts but also socioenvironmental deterioration, with poverty, unemployment

12 JACOBSON, J. L. Environmental Refugees: a yardstick of habitability. Worldwatch Paper 86. Washington, D.C.: Worldwatch Paper 86, 1998. p. 10.

${ }^{13}$ It should be emphasized that the forecasts presented do not have a methodological, scientific base that is robust enough to support the political debates that permeate the subject. As such, they are the targets of several criticisms; amongst these, the definitions to be used as well as the period and distance of displacement to be taken into account for the total number of displaced people due to the adverse effects of climate change are questioned. Indeed, such forecasts are generally based only on the number of individuals living in risk areas, without taking into account the multiplicity of factors that lead to migration. In: IONESCO, D.; MOKHNACHEVA, D.; GEMENE, F. The Atlas of environmental migration. London and New York: Routledge - Taylor and Francis Group, 2017. p. 14.

14 INTERNAL DISPLACEMENT MONITORING CENTRE (IDMC). GRID 2018: Global Report on Internal Displacement. Switzerland: Norwegian Refugee Council (NRC) and Internal Displacement Monitoring Centre (IDMC), 2018. p. v. 
and the increasing destruction of nature, which have caused people displacement ${ }^{15}$.

The current concept of refuge is the product of a long historical process that, despite having enabled the legal protection of persecuted persons, did not provide opportunities for those needing shelter in the new political, economic, social and environmental order over the last decades ${ }^{16}$.

The infeasibility of including those forced to move due to climate change disasters within the traditional refugee concept stems from the difficulty in classifying environmental devastation as persecution, as well as fitting the concept into one of the legal reasons for the concession of refuge ${ }^{17}$. In short, persecution is restricted to the grounds listed in the law, which, for their part, must also revolve around a well-founded fear. In view of this, "climate change, degradation and natural disasters [...] are reasons that can also drive thousands of people out of the place - or even the country - they live in"18.

The first outlines in the conceptualization of this category of people emerged from the attempt to broaden this definition in the 1980s.

\footnotetext{
${ }^{15}$ RAIOL, I. P. C. Crossing borders: legal protection of environmental refugees. Porto Alegre: Núria Fabris, 2010. p. 96.

${ }^{16}$ RAIOL, 2010, p. 96.

${ }^{17}$ LEHMAN, J. Environmental refugees: the construction of a crisis. Prepared for the UHU-EHS Summer Academy, 2009.

${ }^{18}$ RAIOL, 2010, p. 140.
} 
Terms such as environmental refugee ${ }^{19}$, environmental migrant ${ }^{20}$ and the environmentally displaced persons ${ }^{21}$ designate people or groups of people that, faced with imminent environmental adversities in their traditional habitat, whether caused by natural events or induced by human action, make up the wave of migration, both domestically and internationally, on

${ }^{19}$ Essam El-Hinnawi stated in 1985 that environmental refugees were "[...] people who
have been forced to leave their traditional habitat, temporarily or permanently, because of
a marked environmental disruption (natural and/or triggered by people) that jeopardized
their existence and/or seriously the quality of their life". Three years later, Jodi Jacobson
adopted the following designation for environmental refugees: "[...] those displaced
temporarily due to local disruption such as an avalanche or earthquake; those who
migrate because environmental degradation has undermined their livelihood or poses
unacceptable risks to health and those who resettle because land degradation has resulted
in desertification or because of other permanent and untenable changes in their habitat".
Yet, Norman Myers proposed the following concept in $1995:$ "Environmental refuges are
persons who can no longer gain a secure livelihood in their traditional homelands because
of environmental factors of unusual scope, notably drought, desertification, deforestation,
soil erosion, water shortages and climate changes, also natural disasters such as cyclones,
storm surges and floods. In face of these environmental threats, people feel they have
no alternative but to seek sustenance elsewhere, whether within their own countries or
beyond and whether on a semi-permanent or permanent basis". In: SERRAGLIO, D. A. A proteção dos refugiados ambientais pelo direito internacional: uma análise a partir da teoria da sociedade de risco Dissertação (Mestrado) - Pontifícia Universidade Católica do Paraná, Curitiba, 2014. p. 78-80.

${ }^{20}$ In 2007, IOM defined environmental migrants as "persons or groups of persons who, for compelling reasons of sudden or progressive change in the environment that adversely affects their lives or living conditions, are obliged to leave their habitual homes, or choose to do so, either temporarily or permanently, and who move either within their country or abroad." In: IOM, 2009, p. 19.

${ }^{21}$ According to the Appel of Limoges, drafted and published in 2005 by the Frenchman Michel Prieur, so-called environmentally displaced persons are "... individuals, families and communities facing an acute or gradual rupture of their natural environment, inevitably affecting the basic conditions for survival and forcing them, faced with an emergency situation, to leave their usual places of residence, leading them to relocate or settlement at a different location". In: CENTRE DE RECHERCHE INTERDISCIPLINAIRE EN DROIT DE L'ENVIRONNEMENT ET L'URBANISME - CRIDEAU. Projet de Convention Relative au Statut International des Déplaces Environnementaux. Limoges: Cournil Ch., 2009. p. 468. 
a temporary or permanent basis, with a view to safeguarding fundamental guarantees of human rights ${ }^{22}$.

Migratory processes do not derive solely from geophysical activities $^{23}$, but also from misfortunes driven by the development of human practices. In addition to climate change, other environmental causes lead to the forced migration of people, such as scarcity of natural resources, processes that degenerate the environment (and may provoke armed conflicts, as a result), as well as accidents resulting from activities linked to energy production development projects. ${ }^{24}$

While climate change intensifies the vulnerability of people compelled to leave their places of origin, it is not necessarily the sole cause per se. The phenomenon is more of a trigger or catalyst amid an explosive plethora of economic, social, political and/or cultural factors. ${ }^{25}$ As such, the motivations that provoke human mobility are both interdependent and mutually aggravating: where these other factors occur cumulatively, or concurrently, climate change is like a spark on the tinder of already existing humanitarian crises.

Those known as climate-induced migrants may or may not be moving voluntarily. Inititally, voluntary migration arises from the free will of the individual, while involuntary or forced migration involves being compelled to leave the place of residence, or even the country of origin $^{26}$. In practice, however, this becomes a fine distinction, which,

22 RAMOS, 2015, p. 739.

${ }^{23}$ The term is used to "describe the numerous disasters that are induced by a modification of the physical characteristics of the Earth, as opposed to climatic or meteorological conditions. Geophysical disasters - earthquakes, landslides, tsunamis and volcanic eruptions - are thus not directly related to the climate, contrary to a very common belief expressed in public debates". In: IONESCO; MOKHNACHEVA; GEMENE, 2017, p. 38. ${ }^{24}$ PIGUET, E. Climate Change and Forced Migration. New Issues in Refugee Search, Research Paper, n. 153, p. 1-13, 2008.

${ }^{25}$ RAMOS, 2015, p. 740.

${ }^{26}$ RAMOS, E. P. Refugiados Ambientais: em busca do reconhecimento pelo direito internacional. 2011. 150 f. Tese (Doutorado em Direito) - Faculdade de Direito da Universidade de São Paulo, São Paulo, 2011, p. 76. Available at: [http://www.acnur.org] Accessed on 05 Jan 2019, p. 80. 
in turn, hinders the formulation and implementation of the appropriate policies. Commonly, the possibility of having a choice varies according to the individual degree of vulnerability and exposure to the factors mentioned above in conjunction with three main mobility factors - the need, the desire and the ability to migrate ${ }^{27}$. When extreme weather events or measurable sea level rise is present, as examples, it becomes difficult to say that the decision to leave a place of threats to a safer place is voluntary.

Climate-induced migrants may be temporary or permanent and they do not need to cross international borders: it suffices that the individual is compelled to leave his place of habitual residence. As such, it is neither distinguishable nor relevant whether the individual or group has actually crossed an international border ${ }^{28}$.

Most climate-induced migrants do not leave their country of origin: they intend to return "home" as soon as possible ${ }^{29}$. Based on this, there some consensus that those displaced by natural disasters remain within their own borders. In contrast to refugees, the number of individuals crossing the borders of their usual place of residence as a result of environmental disasters is much lower than the number of those internally displaced ${ }^{30}$. While statistics from internally displaced persons

\footnotetext{
${ }^{27}$ It is important to highlight that when people feel the need and the desire to migrate but are unable to do so, they become trapped. This is most often the case for individuals who are already very vulnerable. In these cases, environmental stress functions as an aggravating factor that adds to the systemic economic, demographic and political factors that shape individual livelihoods, access to resources and vulnerability, influencing the need to move. In: IONESCO; MOKHNACHEVA; GEMENE, 2017, p. 28.

${ }^{28}$ RENAUD, F.; et al. Control, adapt or flee: how to face environmental migration? Germany: United Nations University for Environment and Human Security (UNU-EHS), 2007. p. 13.

${ }^{29}$ TIBERGHIEN, F. « Refugiés » écologiques ou climatiques: de nombreuses questions juridiques en suspens. Paris: Association des Revues Plurielles, 2008. p. 18.

30 According to the Guiding Principles on Internal Displacement (1998), internally displaced persons are defined as "persons or group of persons who have been forced or obliged to flee or to leave their homes or places of habitual residence, in particular as a result of or in order to avoid the effects of armed conflict, situations of generalized violence, violations of human rights or natural or human-made disasters, and who have
} 
are not computed instantly for all causes, the levels of environmental displacements keep growing ${ }^{31}$ :

Official statistical data confirms this trend: in its 2008 Global Trends report, the United Nations High Commissioner for Refugees (UNHCR) counted 42 million forcibly displaced people, of which 15.2 million are refugees, 827,000 asylum seekers and 26 million internally displaced ${ }^{32}$.

Given that these movements usually occur from rural to urban centers, debates on the impact of migratory flows and the resulting social, economic, political and cultural dynamics of migrants in cities has begun to gain in prominence. Although (im)migration is a cornerstone of urbanization, when this happens too quickly or without adequate planning, migration is seen as contributing to social instability, shortages of housing, infrastructure and services, as well as causing tensions with the host communities.

\section{The Impacts of Climate Change and the Receiving of Climate- induced Migrants in Urban Areas}

Migration is markedly urban: the majority of migrants and displaced populations move to urban areas and countries are now simultaneously countries of origin, transit and destination ${ }^{33}$. Currently, more than half

not crossed an internationally recognized State border". In: UNITED NATIONS HIGH COMMISSIONER FOR REFUGEES (UNHCR). Guiding Principles on Internal Displacement. New York, 1998. Available at: [http://www.unhcr.org/protection/ idps/43celcff2/guiding-principles-internal-displacement.html] Accessed on 15 Mar. 2019.

${ }^{31}$ IONESCO; MOKHNACHEVA; GEMENE, 2017, p. 28.

${ }^{32}$ RAMOS, 2011, p. 72.

${ }^{33}$ UNITED NATIONS CONFERENCE ON HOUSING AND SUSTAINABLE URBAN DEVELOPMENT. HABITAT III ISSUE PAPERS: Migration and refugees in urban areas. New York, USA: HABITAT III, 2015. p. 02. 
the world's population -3.6 billion people - lives in urban centers ${ }^{34}$. By 2050 , population increase, associated with a high urbanization rate $^{35}$, will boost the number of inhabitants in urban centers from 5.6 to 7.1 billion, comprising $69 \%$ of the total global population ${ }^{36}$. As a result, it is not surprising that urban areas account for about $70 \%$ of economic activity, $70 \%$ of all solid waste produced, $60 \%$ of all available energy and $40 \%$ of GHG emissions ${ }^{37}$.

Cities are both victims and perpetrators of climate change ${ }^{38}$. By attracting individuals in search of job opportunities, professional qualifications and access to goods and services, urban areas end up intensifying GHG emissions into the atmosphere. The growing demand for infrastructure and transport systems requires high energy consumption, affecting the air quality, water availability, land use and waste management ${ }^{39}$.

${ }^{34}$ Urban areas are those that have a high population density and built-up features in comparison to the surrounding areas. The term can also apply to industrial zones and related infrastructure, as well as to cities and towns. In: AVIS, W. R. Urban Governance. Birmingham, UK: GSDRC, University of Birmingham, 2016. p. 03.

${ }^{35}$ In this context, 512 cities had at least 1 million inhabitants in 2016. By 2030, this number will grow to 662.10 additional megacities with more than 10 million inhabitants are projected to emerge by then, bringing the total number to 41 . In: UN HABITAT. Sustainable urbanization in the Paris Agreement: Comparative review of Nationally Determined Contributions for urban content. Nairobi: UN HABITAT, 2017. p. 03.

${ }^{36}$ The global urban population surpassed the rural population in 2007 : while only $30 \%$ of the population was urban in 1950 , this percentage had reached $54 \%$ by 2014 . The IPCC points out that two-thirds of the entire world population will reside in urban centers by 2050. This expansion will occur mainly in developing countries that do not have the necessary infrastructure to support this growth without social and environmental impacts. In: PAINEL BRASILEIRO DE MUDANÇAS CLIMÁTICAS (PBMC). Mudanças Climáticas e Cidades: Relatório Especial do Painel Brasileiro de Mudanças Climáticas. Rio de Janeiro: PBMC, 2016. p. 19.

${ }^{37}$ AVIS, 2016, p. 04.

${ }^{38}$ MCCARNEY, P., H.; BLANCO, J.; CARMIN, M. C. Cities and climate change: the challenges for governance. Cambridge, UK: Cambridge University Press, 2011. p. 258.

${ }^{39}$ MEYER, W. B. THE ENVIRONMENTALADVANTAGES OF CITIES: Countering Commonsense Antiurbanism. Cambridge: The MIT Press, 2013. p. 03. 
At the same time, cities become susceptible to and unable to cope with the impacts of climate change, exposing millions of inhabitants, mostly residing in informal settlements or belonging to vulnerable groups, to various environmental disasters. It is expected that the increase in the number of heatwaves and urban heat islands, more frequent and intense droughts, rains with consequent flooding and rising sea level in coastal areas $^{40}$ will jeopardize not only the water supply and treatment of sewage but also the local energy, transport and public health systems ${ }^{41}$.

Humanity has always had to cope with problems arising from the instability of its surroundings, such as environmental disasters affecting urban infrastructure: "it would be inaccurate to attribute all these problems exclusively to climate change. However, extreme weather events certainly tending to get worse and more frequent." 42

According to the IPCC, climatic variations will undermine the full spectrum of urban functions, infrastructure, services and buildings. The vulnerability of these systems to such phenomena depends on the degree of development, resilience and adaptability ${ }^{43}$. As a result, climate change tends to exacerbate existing pressures, especially in developing countries, "where a large proportion of the population lacks basic sanitation services, where urban road traffic is chaotic and where energy security is constantly under discussion" 44 .

While extreme drought-related events influence the quantity and quality of water resources for city supplies, changes in rainfall patterns

${ }^{40}$ It is noteworthy that most major urban centers are in coastal areas: although they represent only $2 \%$ of the planet's land surface, they account for $13 \%$ of the world population, with Asia being the continent with the highest concentration of people in risk areas. In: XXV PRÊMIO JOVEM CIENTISTA. Impactos da mudanças climáticas nas cidades: Capítulo 07 - Caderno do Professor. Available at: [http://www.seduc.go.gov.br/ intranet/portal/sistemas/not/files/...] Accessed on 05 May 2019. p. 107.

${ }^{41}$ ROSENZWEIG, C. et al. Urban Climate Change in Context - Climate Change and Cities: First Assessment Report of the Urban Climate Change Research Network. Cambridge: Cambridge University Press, 2011. p. 11.

${ }^{42}$ XXV PRÊMIO JOVEM CIENTISTA, 2019, p. 107.

${ }^{43}$ IPCC, 2014, p. 18.

${ }^{44}$ PBMC, 2016, p. 39. 
have more widespread effects, with exposed solid waste in the urban environment obstructing outlets and causing flooding as a result ${ }^{45}$. For its turn, the energy sector is affected not only by energy resources and transformation, but also by the transport, supply and consumption of energy. Still, transportation systems become vulnerable to weather and climate conditions, thus hampering human mobility and quality of life, as well as impeding economic growth ${ }^{46}$.

Public health is directly and indirectly affected. Indirect changes occur in basic aspects of human health, such as water, air and food, when the cycle of life is altered affecting the migration and the distribution of insects as disease vectors and, thus, urban populations are impacted by the dispersal of infectious agents. Direct changes, such as heat waves, extreme temperatures and other weather events, affect human physiology and generate physical trauma, even death ${ }^{47}$.

If the challenges faced by large urban centers due to climate change were not enough already, accelerated urbanization to accomodate climateinduced migrants presents further problems. Individual vulnerability ${ }^{48}$ leads to unprecedented socio-environmental crises, affecting not only social and economic well being but also encroaching on the human rights of newcomers ${ }^{49}$. Migration is usually seen as contributing to shortages in housing, infrastructure, jobs, education and other social services, causing tensions with host communities ${ }^{50}$ :

\footnotetext{
${ }^{45}$ PBMC, 2016, p. 57.

${ }^{46}$ PBMC, 2016, 44-45.

${ }^{47}$ XXV PRÊMIO JOVEM CIENTISTA, 2019, p. 118.
}

${ }^{48}$ Climate-induced migrants are vulnerable to urban violence and criminality, including people trafficking (especially children and women), labor exploitation, fake documents, irregular housing, illegal service provision, unregulated recruitment agencies and corrupt police. In: AVIS, 2016, p. 28.

${ }^{49}$ MURILLO, F. Migrants and rapid urbanization: a new agenda for humanitarian and development urban planning? New York: United Nations Department of Economic and Social Affairs (UN-DESA), 2017. p. 03.

${ }^{50}$ AVIS, 2016, p. 02. 
[...] rapid urbanization, accelerating demand for housing, resource supplies and social and health services, place pressure on already stretched physical, social and regulatory infrastructure, heightening risks and vulnerability. [...] Additional migration to cities is likely to exacerbate pre-existing vulnerabilities related to inequality, poverty, indigence and informality (informal work and settlements), and worsen the situation of those exposed to environmental risk factors. This places further stress on the ability of cities to adapt to climate change ${ }^{51}$.

The economy of cities cannot accommodate new influxes of workers residing in urban settlements. Earning an income through informal employment becomes ways that enable entire families and populations to subsist ${ }^{52}$. Informal urban settlements, known as slums, arise near existing cities and are characterized by residential areas where any guarantee of land use and possession, or even security of living there, is non-existent. Generally, these are regions with housing constructed without municipal planning authorization in risk areas, which limits access to goods and services and basic infrastructures. The spread of these areas is a phenomenon that accompanies urban growth: it is estimated that $25 \%$ of the world's urban population resides in informal settlements, with 213 million new settlers since $1990^{53}$.

Informal employment, in turn, is designated as activities without "strings attached" and/or without proper regulation by government agencies, possibly without benefits such as fixed remuneration, paid leave and social security. As a result, no taxes are collected to support social or public health services. Those in the informal economy face multiple difficulties - undervalued, overworked, often in unhealthy or even unsafe conditions, and underpaid ${ }^{54}$.

${ }^{51}$ WARN, E.; ADAMO, S. B. The impact of climate change: migration and cities in South America. World Meteorological Organization (WTO), Vol. 63(2), 2014. p. 01.

${ }^{52}$ AVIS, 2016, p. 28.

${ }^{53}$ UNITED NATIONS HUMAN SETTLEMENTS PROGRAMME (UN-HABITAT). Streets as public spaces and drivers of urban prosperity. Nairobi: UN-HABITAT, 2013. p. 126.

${ }^{54}$ AVIS, 2016, p. 28. 
As most climate-induced migrants in developing countries move internally to urban centers characterized by poor governance and precarious basic services, many are eventually excluded, thus increasing social tensions and rates of violence ${ }^{55}$.

For sustainable development to cope with these phenomena, there will need to be reforms of programs and services aimed at improving the quality of life of an urban population facing the effects of climate change and the increasing influx of climate-induced migrants. Establishing efficient administrations would enable cities to function and develop sustainably, as well as safeguard the fundamental guarantees to all who reside in them. In other words,

[...] planning has the potential to play a transformational role in improving the quality of life of urban communities and tackling poverty. [...] Governance determines the legal and administrative processes that underpin planning, as well as the roles of formal and informal actors who shape urban change. In many developing countries, effective formal planning is challenge because of a lack of up-to-date mapping, weak development control and enforcement powers, out-of-date planning processes; and limited public knowledge of or compliance with land use regulation. As a result, cities often develop in non-inclusive ways ${ }^{56}$.

The Sustainable Development Goals (SDGs) take on a new relevance in this context, as shown below.

\section{Aligning Urban SDG's with Climate-induced Migration}

Approved at the United Nations Summit for Sustainable Development in September 2015, "Transforming our world: the 2030 Agenda for Sustainable Development" (Agenda 2030) was established with the purpose of revising and updating the Millennium

55 CHAWLA, A. Climate-induced migration and instability: the role of city governments. OEF Research: one earth future, 2017. p. 02.

${ }^{56}$ AVIS, 2016, p. 11. 
Development Goals (MDGs) ${ }^{57} 58$. Agenda 2030 is concerned with the protection of people, the conservation of the planet, the promotion of peace, prosperity and partnerships by guiding national policies and international cooperation activities by 2030. In addition to encompassing 17 Sustainable Development Goals (SDGs), it lists 169 goals, all aimed at outlining a universal, integrated and transforming vision for a better world ${ }^{59}$.

Of these Goals, SDG 11 - To make cities and human settlements inclusive, safe, resilient and sustainable should be highlighted. The specific targets related to SDG 11 aim at the access to safe, adequate and affordable housing; the access to transport systems and improved road safety; inclusive and sustainable urbanization; the safeguarding of global cultural and natural heritage; reducing the number of disaster-related deaths and people affected; reducing the negative environmental impact per capita of cities; as well as universal access to accessible and green public spaces ${ }^{60}$.

57 The Millennium Development Goals (MDGs) are the result of the Millennium Declaration adopted by 191 United Nations (UN) member states in 2000. The document presents 8 objectives and 22 goals that, once implemented internationally, nationally and locally, were responsible for great advances in promoting human development between 2000 and 2015. In: MINISTÉRIO DO PLANEJAMENTO, DESENVOLVIMENTO E GESTÃO. Relatório nacional voluntário sobre os Objetivos do Desenvolvimento Sustentável. Brazil, 2017. Available at: [https://sustainabledevelopment.un.org/] Accessed on 15 May 2019. p. 09.

${ }^{58}$ UNITED NATIONS HUMAN SETTLEMENTS PROGRAMME (UN-HABITAT). SDG GOAL 11 MONITORING FRAMEWORK: A guide to assist national and local governments to monitor and report on SDG Goal 11 indicators. Nairobi: UN-HABITAT, 2016, p. 03.

${ }^{59}$ SDGs involve diverse themes: poverty eradication, food security and agriculture, health, education, gender equality, inequality reduction, energy, water and sanitation, sustainable patterns of production and consumption, protection and sustainable use of oceans and terrestrial ecosystems, inclusive economic growth, infrastructure and industrialization, governance and means of implementation, as well as climate change and sustainable cities. In: MINISTÉRIO DO PLANEJAMENTO, DESENVOLVIMENTO E GESTÃO, 2017, p. 09.

${ }^{60}$ NAÇÕES UNIDAS NO BRASIL (ONU-BR). OBJETIVO 11: Tornar as cidades e os assentamentos humanos inclusivos, seguros, resilientes e sustentáveis. Available at: [https://nacoesunidas.org/pos2015/ods11/] Accessed on 15 May 2019. 
This SDG works with the concept of resilient cities: urban aereas prepared for current and future adversities, in such a way as to limit the magnitude and severity of environmental misfortunes. As soon as these occur, they are able to respond quickly, equitable and efficiently ${ }^{61}$. Put another way, "a resilient city describes the capacity of cities to function, where the people who live and work in cities, particularly the poor and vulnerable, survive and thrive, no matter what the stress or shocks they encounter" 62 .

This requires the organization of services and infrastructure to support all sectors of the urban population. Cities must share information about who is exposed and who is vulnerable. Sustainable urbanization requires a competent, inclusive and transparent local government, as well as the empowerment of citizens to participate, decide and plan their city with the local authorities ${ }^{63}$.

Urbanization processes can make a significant contribution to the economic, cultural and social development of cities when well administeres. A higher population density enables governments to deliver essential infrastructure and services more easily in urban areas at a relatively low cost per capita. Livable and sustainable cities have a knockon effect in terms of providing rural populations with greater access to services such as education and healthcare, while also empowering them economically ${ }^{64}$. Therefore, it can help the "world to overcome some of its major global challenges, including poverty, inequality, environmental degradation, climate change, fragility and conflict, which are all critical elements of the 2030 Agenda" ${ }^{65}$.

${ }^{61}$ THE WORLD BANK GROUP. Guia de Adaptação à Mudança Climática nas Cidades: Sumário Executivo. Washington, DC: The World Bank, 2016, p. 06.

${ }^{62}$ PBMC, 2016, p. 21.

${ }^{63}$ ONU-BR, 2019.

${ }^{64}$ UNITED NATIONS POPULATION FUND (UNFPA). Sustainable Development and Population Dynamics: Placing people at the center. 2013. Available at: [http://www. unfpa.org/press/sustainable-development-and-population-dynamics-placing-peoplecentre] Accessed on 15 May 2019. p. 04.

${ }^{65}$ UN-HABITAT, 2016, p. 06. 
By endorsing an objective that specifically addresses cities, international community has recognized urbanization process and urban centers as transforming forces for sustainable development. Although the SDG 11 does not refer to the role-played and the contributions made by climate-induced migrants to this process, paragraph 29 of Agenda 2030 states:

We recognize the positive contributions of migrants for inclusive growth and sustainable development. We also recognize that international migration is a multi-dimensional reality of major relevance for the development of countries of origin, transit and destination, which requires coherent and comprehensive responses. We will cooperate internationally to ensure safe, orderly and regular migration involving full respect for human rights and the humane treatment of migrants regardless of migration status, of refugees and of displaced persons ${ }^{66}$.

Additionally, SDG 10 - Reduce inequality within and among countries is relevant. It highlights the need to facilitate the orderly, safe, regular and responsible human migration and mobility, including by implementing well planned and managed policies ${ }^{67}$.

Urbanization and migration are clearly related since urban growth processes always involve the influx of new inhabitants. Beyond population changes due to variations in fertility and mortality rates, population of urban areas around the world are often affected by climate migratory movements: within and between countries, between rural and urban areas, and between different world regions ${ }^{68}$. Despite the scale

${ }^{66}$ UNITED NATIONS (UN). Transforming our world: the 2030 Agenda for Sustainable Development. Available at: [https://nacoesunidas.org/pos2015/agenda2030/] Accessed on 15 May 2019.

${ }^{67}$ NAÇÕES UNIDAS NO BRASIL (ONUBR). OBJETIVO 10: Reduzir a desigualdade dentro dos países e entre eles. Available at: [https://nacoesunidas.org/pos2015/ods10/] Accessed on 15 May 2019.

68 UNITED NATIONS EDUCATIONAL, SCIENTIFIC AND CULTURAL ORGANIZATION (UNESCO). Cities welcoming refuges and migrants. Paris: UNESCO, 2016. p. 11. 
of climate-induced migration, many cities and local governments fail to consider this factor when planning urban development. Migrants are generally overlooked in discourses on urbanization and urban governance ${ }^{69}$ or viewed as a problem rather than a potential asset. This shall be examined below.

\section{The Recognition and Relevance of Climate-induced Migration in Urban Areas}

While climate-induced migration into urban areas is one of the challenges of the $21^{\text {st }}$ century, this category of people is neglected in discourses related to urbanization processes. Deprived of adequate protection mechanisms, these inhabitants can be excluded or become invisible to society: "the generic urbanization model over the past decades has fostered segregation over integration" 70 .

In addition to accentuating homelessness and limiting access to goods and services, climate-induced migration can cause tensions in local communities, and be seen as a threat, synonymous of social instability and/or crisis by the target destinations ${ }^{71}$. Rather than highlighting the benefits of climate-induced migrants in urban life, contemporary society has traditionally sought ways to hamper their access to urban centers ${ }^{72}$. To advance sustainable development, the dynamics of population flows provide opportunities for the implementation of the $\mathrm{SDGs}^{73}$ :

Cities everywhere have long been shaped by migration. They can be understood as the spatial, political, economic and cultural

\footnotetext{
${ }^{69}$ Urban governance must also reflect SDG 13 - Take urgente action to combat climate change and its impacts. Displacements caused by the adverse effects of climate change are not addressed by this SDG.

${ }^{70}$ AMRITH, M. Cities for All? Migration and the New Urban Agenda. United Nations University, 2016. Available at: [https://unu.edu/publications/articles/cities-for-allmigration-and-the-new-urban-agenda.html] Accessed on 15 Mar. 2019. p. 02.

${ }^{71}$ AVIS, 2016, p. 02.

${ }^{72}$ AMRITH, 2016, p. 02.

${ }^{73}$ UNFPA, 2013, p. 03.
} 
translation of population dynamics, markets and services, among other factors. Cities emerge from and develop through processes of migration and concentration. Newcomers - whether from other cities within and beyond national border or from rural areas contribute to the increasing diversity and complexity of interactions in cities $^{74}$.

The arrival of new inhabitants, notwithstanding their vulnerable status, offers social, economic and cultural advantages to urban centers through their contribution to reducing poverty and improving human development - if their arrival is well managed. Migration processes boost labor market ${ }^{75}$, generate new demands for goods and services, promote income generation ${ }^{76}$ and increase tax revenues ${ }^{77}$. Climate-induced migrants stimulate economic growth and employment, also acting as a powerful source for innovation and experience that can reduce the impacts of natural hazards and foster adaptation ${ }^{78}$.

Several cities have thus been working to promote the reception of climate-induced migrants, seeking ways to provide them with access to basic services and to include them in the urban network without violating fundamental guarantees. These efforts offer the "potential to transform the discourse and politics of migration by recognizing the rich social, cultural

${ }^{74}$ UNESCO, 2016, p. 21.

${ }^{75}$ In countries with aging populations, migrants provide a workforce and thus foster the economy. Over the next 15 years, the majority of the world's countries will experience a decline in their workforces, requiring the arrival of new people. As an example, the working age population ( 22 to 66 years old) of Germany is predicted to decline by almost a quarter (about 13 million people) between 2013 and 2040. In: UNESCO, 2016, p. 15.

${ }^{76}$ Climate-induced migrants can also contribute to their communities of origin through transfer of remittances (transfer of money by a foreign worker to an individual in their home country). The money sent home by migrants competes with international aid as one of the largest global financial flows: annual remittances to developing countries alone approach U\$ 500 billion. In: UNFPA, 2013. p. 04.

77 INTERNATIONAL ORGANIZATION FOR MIGRATION (IOM). UN-HABITAT Event recognizes contribution of migrants to cities. Available at: [https://www.iom. int/news/un-migration-agency-un-habitat-event-recognize-contribution-migrants-cities] Accessed on 15 Mar. 2019.

${ }^{78}$ WARN; ADAMO, 2014, p. 01. 
and economic contributions of migrants to urban life, while allowing us to imagine the possibilities for migrants to feel a sense of belonging at an urban level"79.

Aware of this, following the publication of the New York Declaration on Refugees and Migrants in September $2016^{80}$, UN member states and relevant stakeholders participated in the United Nations Conference on Housing and Sustainable Urban Development (HABITAT III), held in Quito, to discuss global policies for cities in the coming decades. The conference, organized by the United Nations Human Settlements Programme (UN-HABITAT) ${ }^{81}$, aimed to reinvigorate the global commitment to sustainable urbanization and focused on the development of guidelines to the implementation of a new non-binding document. Among its main objectives, to secure renewed political commitment for sustainable urban development, assess accomplishments

\footnotetext{
${ }^{79}$ AMRITH, 2019, p. 03.

${ }^{80}$ The New York Declaration contains bold commitments to protect the human rights of all refugees and migrants, regardless of status, and presented the provisions to the negotiations that lead to the adoption of the Global Compact for Safe, Orderly and Regular Migration by the end of 2018. Both documents acknowledge environmental factors as drivers of migration and also recognize the positive contributions made by migrants to economic and social development in their host countries. In: UNITED NATIONS (UN).
} Resolution adopted by the General Assembly on 19 September 2016: New York Declaration for Refugees and Migrants. Available at: [www.un.org/en/ga/search/view_ doc.asp?symbol=A/RES/71/1] Accessed on 15 Mar 2019.

${ }^{81}$ The UN-HABITAT is the United Nations agency for human settlements and sustainable urban development. It was established in 1978 as an outcome of the of the United Nations Conference on Human Settlements and Sustainable Urban Development (HABITAT I) held in Vancouver in 1976. On this occasion, governments recognized the need for sustainable human settlements and the consequences of rapid urbanization, especially in the developing countries. The mandate of UN-HABITAT derives from the Habitat Agenda, adopted twenty years later during the United Nations Conference on Human Settlements (HABITAT II) in Istanbul. The Habitat Agenda presents an action plan for adequate shelter for all, with the notion of sustainable human settlements driving development in an urbanizing world. It was not until HABITAT III, in 2016, that migration was included in the UN-HABITAT agenda. See HIII. Available at: [http://habitat3.org] Accessed on 20 June 2019. 
to date, address poverty, identify and address new and emerging challenges are noteworthy ${ }^{82}$.

HABITAT III was the first UN global event after the adoption of the 2030 Agenda its SDGs and it offered "a unique opportunity to discuss the important challenge of how cities, towns and villages are planned and managed in order to fulfill their roles as drivers of sustainable development and, hence, shape the implementation of new global development and climate change goals" $" 83$.

The New Urban Agenda was developed as a result, providing guidance on issues such as urban planning and design and the legal frameworks to enhance positive outcomes of urbanization ${ }^{84}$. Besides being universal in scope, participatory and people-centred, it acknowledges the protection of the planet and and has a long-term vision, setting out priorities and actions at the global, regional, national, subnational and local level that policy makers can adopt based on their needs ${ }^{85}$.

The Agenda was built on the right to adequate housing as a component of the right to an adequate standard of living; universal access to safe and affordable drinking water and sanitation; equal access for all to public goods and quality services, such as food security and nutrition, health, education, infrastructure, mobility and transportation, energy, air quality and livelihoods; participatory, civic engagement and social cohesion and inclusion; disaster-risk reduction; inclusive and sustainable economic growth; and, finally, on the protection, conservation, restoration and promotion of ecosystems and biodiversity ${ }^{86}$.

${ }^{82}$ UNITED NATIONS CONFERENCE ON HOUSING AND SUSTAINABLE URBAN DEVELOPMENT. HABITAT III (HIII). Quito: HABITAT III (H-III). Available at: [http://habitat3.org] Accessed on 20 June 2019.

${ }^{83}$ H-III, 2019.

${ }^{84}$ UNITED NATIONS CONFERENCE ON HOUSING AND SUSTAINABLE URBAN DEVELOPMENT. HABITAT III ISSUE PAPERS: Migration and refugees in urban areas. New York: HABITAT III (H-III), 2015. p. 01.

${ }^{85}$ UN-HABITAT. Action Framework for Implementation of the New Urban Agenda. New York, 2017. Available at: [http://nua.unhabitat.org/AFINUA19thApr.pdf] Accessed on 20 June 2019.

${ }^{86}$ UN-HABITAT, 2017. 
Despite its non-binding nature and the lack of monitoring mechanisms ${ }^{87}$, the document emphasizes the respect for the humane treatment of migrants through support for the cities that host them, in a spirit of international cooperation. While recognizing that migration to urban areas is fraught with complications, the New Urban Agenda recognizes this can still provide significant social, economic and cultural contributions to urban life. It also reinforces the relevance of local authorities in developing structures that strengthen urban-rural links and safe, orderly and regular migration processes through previously stipulated migration policies ${ }^{88}$.

The New Urban Agenda thus aims to meet the needs of climateinduced migrants in urban areas by adopting an inclusive urbanization model that takes into account the entire migration process - not merely the problems encountered at the final destination but also at place of origin and during transit. This way, it becomes possible to uphold human dignity "while building on their capacity and responding to humanitarian and development concerns in synergy" $"$. Regarding its preeminent commitment to inclusion,

Heterogeneity is the lifeblood of cities. Cities attract different people and must also embrace diversity, create a safe speace for it and make inclusion their mantra. When they succeed in doing so, cities are preeminent places for the enjoyment of equal rights and opportunities, as well as their fundamental freedoms, guided by the purposes and principles of the Charter of the United Nations ${ }^{90}$.

The document is based on the precepts of the Universal Declaration of Human Rights ${ }^{91}$ in recognizing the fundamental guarantees of all those

\footnotetext{
${ }^{87}$ BEIER, R.; FRITZSCHE, J. Refugee and the city: UN-Habitat's New Urban Agenda. Forced Migration Review, n. 55, 2017. Available at: [http://www.fmreview.org/shelter] Accessed on 15 Mar. 2019.

${ }^{88}$ See Article 28 of the New Urban Agenda.

${ }^{89}$ H-III, 2015, p. 04.

${ }^{90}$ UN-HABITAT, 2017.

${ }^{91}$ Human rights principles and standards of a broader scope that apply to migrants are contained in the following fundamental human rights conventions: the International
} 
who migrate regardless of their status: "a human rights-based approach to the city entails multi-stakeholder cooperation guided by principles of democracy, participation, responsible leadership, transparency, accountability, non-discrimination, empowerment and the rule of law"92.

The right to the city was also considered. A shared vision of a city for all, involving "the equitable use of cities according to principles of sustainability, democracy, equity and social justice", would facilitate the inclusion of those who inhabit it, whether present or future generations, without discrimination. The right entails the development of fair, equitable, healthy, accessible, resilient and sustainable urban centers and human settlements to foster prosperity and quality of life for all ${ }^{13}$.

Referring to the right to the city, the New Urban Agenda includes a comprehensive view of the territory, respect for human rights and gender equality, the social function of the land and capture of the value generated by urban development, the guarantee of the involvement of citizens and society in the design, implementation, monitoring and evaluation of public policies and budgets, the coordination within and among the spheres of government, recognition of the contribution of the informal sector to the urban economy, as well as a commitment to responsible and sustainable management of natural, energy, material and cultural resources ${ }^{94}$.

Convention on the Elimination of all Form of Racial Discrimination (1965), the International Covenant on Civil and Political Rights (1966), International Covenant:SEPPion Economic, Social and Cultural Rights (1966), the Convention on the Elimination of all Forms of Discrimination against Women (1979), the Convention on the Rights of the Child (1989), the Convention on the Rights of Persons with Disabilities (2006) as well as the Convention on Discrimination in Employment and Occupation No. 111 (1958) of the International Labor Organization (ILO).

${ }^{92}$ UNESCO, 2016, p. 08.

${ }^{93}$ UNITED NATIONS CONFERENCE ON HOUSING AND SUSTAINABLE URBAN DEVELOPMENT. New Urban Agenda. Quito: HABITAT III (H-III). Available at: [http://habitat3.org/wp-content/uploads/NUA-English.pdf] Accessed on 15 Mar. 2019.

${ }^{94}$ ALOMAR, J. S. C. O direito à cidade e a Nova Agenda Urbana da ONU: Perspectivas para a inovação urbanística no contexto do fortalecimento do neoliberalismo. XVII ENANPUR: Perspectivas para o planejamento urbano e regional, São Paulo, 2017. p. 06. 
Under a holistic perspective, mention should be made of Pope Francis' message ${ }^{95}$ for the celebration of World Peace Day, early in 2018. The text Migrants and Refugees: Men and Women in Search of Peace addresses the rhetoric that focuses on national security risks and the burden of receiving new arrivals of migrants into urban centers and, as such, disregards the human dignity to be given to all, without distinction ${ }^{96}$ :

How beautiful are the cities that overcome unhealthy distrust and integrate those who are different, making this integration a new factor of progress! How enchanting are the cities that, already in their architectural design, are full of spaces that unite, relate and favor the recognition of others ${ }^{97}$.

According to the Pontiff, the increasing presence of people from different origins living together in the same urban areas can become a positive and creative sociocultural factor. Seeing migration as an "opportunity to build a future of peace" $" 98$ and, as a believer, he states that when we turn that a gaze of faith "to migrants and refugees, we discover that they do not arrive empty-handed. They bring their courage, skills, energy and aspirations, as well as the treasures of their own cultures; and in this way, they enrich the lives of the nations that receive them" ${ }^{\text {"99. }}$

\footnotetext{
${ }^{95}$ Despite being the leader of the Roman Catholic Apostolic Church and current Head of State of the Vatican, it is important to highlight that Pope Francis' statements often rely on official legal declarations, such as the Earth Charter, with explicit reference in paragraph 207 of Chapter Six - Ecological Education and Spirituality of Laudato Si' Encyclical Letter on Care for Our Common Home. The 2000 Earth Charter is an international declaration of fundamental values and principles considered useful by its supporters for building a just, sustainable and peaceful global society in the $21^{\text {st }}$ century.

${ }^{96}$ POPE FRANCIS. Message of His Holiness Pope Francis for the celebration of the 51st World Day Of Peace 2018: migrants and refugees - men and women in search of peace. Vatican: Libreria Editrice Vaticana, 2018. p. 02. Available at: [http://w2.vatican. va/content/francesco/pt/messages] Accessed on 15 Mar. 2019.

97 POPE FRANCIS. Carta Encíclica Laudato Si': Sobre o cuidado da casa comum. Vatican: Edições Paulinas, 2015. p. 48.

${ }^{98}$ POPE FRANCIS, 2018, p. 03.

${ }^{99}$ POPE FRANCIS, 2018, p. 04.
} 
Besides recognizing the benefits of migration, since those who arrive ultimately respond to the needs and boost the economy of nations that receive them, Pope Francis also reinforces the indispensability of rule of law precepts in relation to this category of people, in the sense of prevent illegal and inhumane abuses ${ }^{100}$.

The Head of the Catholic Church points out four characteristics necessary for the proper reception of migrants in urban centers: welcoming, protecting, promoting and integrating. ${ }^{101}$ While welcoming appeals to the premise of expanding the options for remaining lawfully and balancing social tensions while safeguarding Human Rights, protecting reminds us of the duty to actively respect the dignity of those who seek shelter and prevent their exploitation. Promoting refers to supporting full human development, especially in education, at all levels. Finally, integration means allowing everyone to participate fully in the life of the society that receives them, "as part of a process of mutual enrichment and fruitful cooperation in service of the integral human development of the local community" 102 .

To ensure that cities welcome climate-induced migrants, it is essential to have a deliberate rights-based approach to city governance. This means having universal and equal access to basic human and social services, equality of treatment and opportunity. Thus, urban governance needs to supress discrimination, racism or xenophobia. Cities must be genuine places of diversity, offering the best prospects for future development, engaging all stakeholders in decision-making and implementing multi-level governance, dialogue, cooperation and accountability:

We need better policies, more engagement and adequate support for local governments to harness the significant benefits from migrants

\footnotetext{
${ }^{100}$ This statement can be related to SDG 16 - Peace, Justice and Strong Institutions, which aims to promote peaceful and inclusive societies for sustainable development, provide access to justice for all and build effective, accountable and inclusive institutions at all levels.

${ }^{101}$ POPE FRANCIS, 2018, p. 04.

102 POPE FRANCIS, 2018, p. 04.
} 
in our cities. In order to enable dignified support of migrants who come in large numbers, governments at all levels need to empower local actors and collaborate effectively to promote people-centered integration policies which both protect the human rights of migrants, and also to improve the quality of life for all those living in cities $^{103}$.

For the above reasons, if well managed, urban centers can stimulate sustainable development and provide better socioeconomic conditions not only for current inhabitants, but also for all those who migrate there. Urban governance must be developed to be capable of implementing comprehensive, balanced and inclusive policies, cover all sectors of the community equally. Outcomes depend on factors such as the nature of local democratic institutions and processes, the resources available and the ability of climate-induced migrants to organize and articulate demands ${ }^{104}$.

Climate-induced migration is no longer classified as something new by the international community. The novelty seems to lie in the complexity of the challenges imposed on the dynamics of a society proposing to achieve sustainable development and real equality through outdated policies riddled with lacunas. Although romanticized this ideal of cities welcoming climate-induced migrants with open arms, significant challenges remain.

While States remain locked in the anachronism of egoistic sovereignty and fail, historically, cities often held an autonomous position. When faced with global risks, such as climate change, they are more open to cooperative cosmopolitan politics and adaptation to new realities. According to Beck, urban areas "are the main places where the clashes of global risks become matters of everyday experience and

${ }^{103}$ INTERNATIONAL ORGANIZATION FOR MIGRATION (IOM). UN-HABITAT Event recognizes contribution of migrants to cities. Available at [https://www.iom. $\mathrm{int} /$ news/un-migration-agency-un-habitat-event-recognize-contribution-migrants-cities] Accessed on 15 Mar. 2019.

${ }^{104}$ AVIS, 2016, p. 06. 
politics" 105 and, for this reason, they "turn into pioneers which take up the challenge of cosmopolitan modernity as an experiment to find answers to a world at risk" 106 . Hence, it is possible to frame cities as actors that play an important role in tackling climate change and climate-induced migration.

As cities can take individually binding decisions, their decisions collectively are embedded in an active way in international law making. Besides, they are subject to traditional democratic practices and challenges: as example, their mayors have to be re-elected based on how much they have achieved when faced with unplanned urban growth - as cities are the primary destination for internal and cross-border forced migrants - and the ability to keep large towns functioning in a sustainable way ${ }^{107}$.

It remains to be seen if urban areas will be able to evolve toward a central position similar to that which they inhabited long ago, before the nation-state society. Even though humankind began its paths towards politics in the polis - the city -, for millennia, cities relied on monarchy, empires and nation-states to produce and reproduce social and political order. As the current system does not present effective responses to climate migration and is failing in the face of global risks, such as climate change and its adverse effects, cities might once again play a relevant role.

${ }^{105}$ BECK, U. The metamorphosis of the world. Cambridge, UK: Polity Press, 2016. p. 180.

${ }^{106}$ BECK, 2016, p. 180.

${ }^{107}$ As example, in New York City, all migrants (regardless of their status) are eligible for an identification card giving them access to many services in the city. Meanwhile, Sao Paulo has established a municipal migration policy developed in accordance with human rights principles and non-discrimination. It draws upon migrants' voices through participative consultations. Further, cities in Germany are making novel uses of urban spaces and infrastructure to house recently arrived migrants, while volunteer-led projects among urban citizens have emerged to foster a welcome culture that can lead to sustainable forms of inclusion. In: AMRITH, 2016, p. 03. 


\section{Conclusion}

Migration processes have been intensified due to the impacts of climate change. As a large part of climate-induced migrants remains within their national borders, with movements usually taking place from rural to urban areas, debates on the effects of human flows in cities have come to the fore. Even though (i)migration is considered one of the central aspects of urbanization, the arrival of new inhabitants in urban spaces is seen as being responsible for the arising of socioeconomic instabilities.

By increasing GHG emissions into the atmosphere, cities become incapable to cope adequately with the consequences of climate change, exposing vulnerable groups to a variety of hazards. In addition to that, climate-induced migrants also have to deal with other difficulties stemming from rapid-urbanization: vulnerability, associated with environmental degradation, give rise to unprecedented socioenvironmental crises, affecting not only social and economic aspects but also threatening human rights.

Thus, urban planning and governance can contribute to the sustainable expansion of cities. Besides sustained economic growth and environmental protection, they also promote inclusive and social development. It was in this context that SDG 11 was investigated.

Albeit addressing cities as transformative forces of sustainable development, SDG 11 does not refer to the role played by climate-induced migration to urbanization processes. One should keep in mind that the arrival of migrants offers social, economic and cultural advantages, reducing poverty and fostering human development.

As such, the New Urban Agenda was explored. Established to rethink the way human settlements are being planned and managed, it highlights the need to respect migrants' human rights - especially the right to the city. It also acknowledge the positive contributions of migration to urban life.

Ensuring welcoming cities for climate-induced migrants requires not only access to basic goods and services but also equal treatment and opportunities. Likewise, urban centers should be recognized as dynamic 
places and drivers of multiculturalism. They can enhance socioeconomic conditions for their inhabitants and for all those who move towards them.

Therefore, displacements associated with the adverse effects of climate change are no longer considered as something new by the international community. The novelty seems to lie in the complexity and difficulty of developing effective solutions to the topic. In this sense, urban planning poses challenges to a society that seeks to achieve sustainable development through outdated and gap-filled policies.

\section{References}

\section{ALOMAR, J. S. C. O direito à cidade e a Nova Agenda Urbana} da ONU: Perspectivas para a inovação urbanística no contexto do fortalecimento do neoliberalismo. XVII ENANPUR: Perspectivas para o planejamento urbano e regional, São Paulo, 2017.

AMRITH, M. Cities for All? Migration and the New Urban Agenda. United Nations University, 2016. Available at: https:/unu.edu/ publications/articles/cities-for-all-migration-and-the-new-urban-agenda. html. Accessed on: 15 Mar. 2019.

AVIS, W. R. Urban Governance. Birmingham, UK: GSDRC, University of Birmingham, 2016.

BECK, U. The metamorphosis of the world. Cambridge, UK: Polity Press, 2016.

BEIER, R.; FRITZSCHE, J. Refugee and the city: UN-Habitat's New Urban Agenda. Forced Migration Review, n. 55, 2017. Available at: http://www.fmreview.org/shelter. Accessed on: 15 Mar. 2019.

BRADBROOK, A.; OTTINGER, R. Energy law and sustainable development. Geneva, Switzerland: IUCN, 2003.

BRASIL. MINISTÉRIO DO PLANEJAMENTO, DESENVOLVIMENTO E GESTÃO. Relatório nacional voluntário sobre os Objetivos do Desenvolvimento Sustentável. Brasil, 2017. Available at: https://sustainabledevelopment.un.org/. Accessed on: 15 May 2019. 
CENTRE DE RECHERCHE INTERDISCIPLINAIRE EN DROIT DE L'ENVIRONNEMENT ET L'URBANISME - CRIDEAU. Projet de Convention Relative au Statut International des Déplaces Environnementaux. Limoges: Cournil Ch., 2009.

CHAWLA, A. Climate-induced migration and instability: the role of city governments. OEF Research: one earth future, 2017.

FERNANDES, E. A. Meio ambiente e direitos humanos: o deslocamento de pessoas por causas ambientais agravadas pelas mudanças climáticas. Curitiba: Juruá, 2014.

INTERGOVERNMENTAL PANEL ON CLIMATE CHANGE (IPCC). Working Group I Contribution to the IPCC $5^{\text {th }}$ Assessment Report. Climate Change 2013: the Physical Science Basis. Sweden: 2013.

INTERNAL DISPLACEMENT MONITORING CENTRE (IDMC). GRID 2018: Global Report on Internal Displacement. Switzerland: Norwegian Refugee Council (NRC) and Internal Displacement Monitoring Centre (IDMC), 2018.

INTERNATIONAL ORGANIZATION FOR MIGRATION (IOM). Migration, environment and climate change: Assessing the evidence. Switzerland: IOM, 2009.

INTERNATIONAL ORGANIZATION FOR MIGRATION (IOM). UN-HABITAT Event recognizes contribution of migrants to cities. Available at: https://www.iom.int/news/un-migration-agency-un-habitatevent-recognize-contribution-migrants-cities. Accessed on: 15 Mar. 2019. IONESCO, D.; MOKHNACHEVA, D.; GEMENE, F. The Atlas of environmental migration. London and New York: Routledge - Taylor and Francis Group, 2017.

JACOBSON, J. L. Environmental Refugees: a yardstick of habitability. Worldwatch Paper 86. Washington, D.C.: Worldwatch Paper 86, 1998.

JURAS, L. A. G. M. Aquecimento global e mudanças climáticas: uma introdução. Brasília: Biblioteca Digital da Câmara dos Deputados, 2008. 
LEAL-ARCAS, R. Climate change and international trade. Cheltenham, UK: Edward Elgar Publishing Limited, 2013.

LEHMAN, J. Environmental refugees: the construction of a crisis. Prepared for the UHU-EHS Summer Academy, 2009.

MCCARNEY, P., H.; BLANCO, J.; CARMIN, M. C. Cities and climate change: the challenges for governance. Cambridge, UK: Cambridge University Press, 2011.

MEYER, W. B. The Environmental Advantages of Cities: Countering Commonsense Antiurbanism. Cambridge: The MIT Press, 2013.

MURILLO, F. Migrants and rapid urbanization: a new agenda for humanitarian and development urban planning? New York: United Nations Department of Economic and Social Affairs (UN-DESA), 2017.

MYERS, N. Environmental exodus: an emergent crisis in the global arena. Washington: Project of the Climate Institute, 1995.

NAÇÕES UNIDAS NO BRASIL (ONU-BR). OBJETIVO 11: Tornar as cidades e os assentamentos humanos inclusivos, seguros, resilientes e sustentáveis. Available at: https://nacoesunidas.org/pos2015/ods11/. Accessed on: 15 May 2019.

PAINEL BRASILEIRO DE MUDANÇAS CLIMÁTICAS (PBMC). Mudanças Climáticas e Cidades: Relatório Especial do Painel Brasileiro de Mudanças Climáticas. Rio de Janeiro: PBMC, 2016.

POPE FRANCIS. Carta Encíclica Laudato Si': Sobre o cuidado da casa comum. Vatican: Edições Paulinas, 2015.

POPE FRANCIS. Message of his Holiness Pope Francis for the Celebration of the $51^{\text {st }}$ World Day of Peace. Migrants and refugees: men and women in search of peace. Vatican: Libreria Editrice Vaticana, 2018. p. 2. Available at: https://w2.vatican.va/content/francesco/en/ messages/peace/documents/papa-francesco_20171113_messaggio51 giornatamondiale-pace2018.html. Accessed on: 15 Mar. 2019. 
PIGUET, E. Climate Change and Forced Migration. New Issues in Refugee Search, Research Paper, [S.l.], n. 153, p. 1-13, 2008.

RAIOL, I. P. C. Ultrapassando fronteiras: a proteção jurídica dos refugiados ambientais. Porto Alegre: Núria Fabris, 2010.

RAMOS, É. P. Refugiados Ambientais: em busca do reconhecimento pelo direito internacional. 2011. 150f. Tese (Doutorado em Direito) Faculdade de Direito da Universidade de São Paulo, São Paulo, 2011, p. 76. Available at: http://www.acnur.org/. Accessed on: 5 Jan. 2019.

RAMOS, Erika Pires. Refugiados, migrantes ou deslocados ambientais: uma abordagem inspirada na proteção do meio ambiente e nos direitos humanos. In: LEITE, José Rubens Morato (coord.). Manual de Direito Ambiental. 1. ed. São Paulo: Saraiva, 2015.

RENAUD, F. et al. Control, adapt or flee: how to face environmental migration? Germany: United Nations University for Environment and Human Security (UNU-EHS), 2007.

ROBINSON, N.A. Environmental Law: is an obligation erga omnes emerging? Permanent Mission of Colombia to the United Nations: Panel Discussion at the United Nations regarding the Advisory Opinion (OC23/17) of the Inter-American Court of Human Rights of 15 November 2017. Available at: https://www.iucn.org/sites/dev/files/content/ documents/2018/environmental_law_is_an_obligation_erga_omnes emerging_interamcthradvisoryopinionjune2018.pdf. Acess on: 4 Jun. 2019.

ROSENZWEIG, C. et al. Urban Climate Change in Context - Climate Change and Cities: First Assessment Report of the Urban Climate Change Research Network. Cambridge: Cambridge University Press, 2011.

SERRAGLIO, D. A. A proteção dos refugiados ambientais pelo direito internacional: uma análise a partir da teoria da sociedade de risco. 2014. 114p. Dissertação (Mestrado) - Pontifícia Universidade Católica do Paraná, Curitiba, 2014. 
THE WORLD BANK GROUP. Guia de Adaptação à Mudança Climática nas Cidades: Sumário Executivo. Washington, DC: The World Bank, 2016.

TIBERGHIEN, F. "Refugiés" écologiques ou climatiques: de nombreuses questions juridiques en suspens. Paris: Association des Revues Plurielles, 2008.

UNITED NATIONS (UN). Resolution adopted by the General Assembly on 19 September 2016: New York Declaration for Refugees and Migrants. Available at: http://www.un.org/en/ga/search/view_doc. asp?symbol=A/RES/71/1. Accessed on: 15 Mar. 2019.

UNITED NATIONS (UN). Sustainable Development Knowledge Platform: Sustainable Development Goal 16. Available at: https:// sustainabledevelopment.un.org/sdg16. Acessed on: 20 Jun. 2019.

UNITED NATIONS (UN). Transforming our world: the 2030 Agenda for Sustainable Development. Available at: https://nacoesunidas.org/ pos2015/agenda2030/. Accessed on: 15 May 2019.

UNITED NATIONS (UN). United Nations Convention on Climate Change. Rio de Janeiro: UN, 1992. Available at: https:/unfecc.int/ resource/docs/convkp/conveng.pdf. Accessed on: 15 Mar. 2019.

UNITED NATIONS CONFERENCE ON HOUSING AND SUSTAINABLE URBAN DEVELOPMENT. Habitat III Issue Papers: Migration and refugees in urban areas. New York, USA: HABITAT III, 2015.

\section{UNITED NATIONS CONFERENCE ON HOUSING AND} SUSTAINABLE URBAN DEVELOPMENT. Action Framework for Implementation of the New Urban Agenda. New York, 2017. Available at: http://nua.unhabitat.org/AFINUA19thApr.pdf. Accessed on: 20 Jun. 2019.

UNITED NATIONS CONFERENCE ON HOUSING AND SUSTAINABLE URBAN DEVELOPMENT. Habitat III (HIII). Quito: Habitat III (H-III). Available at: http://habitat3.org. Accessed on: 20 Jun. 2019. 
UNITED NATIONS CONFERENCE ON HOUSING AND SUSTAINABLE URBAN DEVELOPMENT. New Urban Agenda. Quito: Habitat III (H-III). Available at: http://habitat3.org/wp-content/ uploads/NUA-English.pdf. Accessed on: 15 Mar. 2019.

UNITED NATIONS EDUCATIONAL, SCIENTIFIC AND CULTURAL ORGANIZATION (UNESCO). Cities welcoming refuges and migrants. Paris: UNESCO, 2016.

UNITED NATIONS HIGH COMMISSIONER FOR REFUGEES (UNHCR). Convention Relating to the Status of Refugees. Geneva, 1951. Available at: http://www.unhcr.org/3b66c2aa10. Accessed on: 15 Mar. 2019.

UNITED NATIONS HIGH COMMISSIONER FOR REFUGEES (UNHCR). Guiding Principles on Internal Displacement. New York, 1998. Available at: http://www.unhcr.org/protection/idps/43ce1cff2/ guiding-principles-internal-displacement.html\#. Accessed on: 15 Mar. 2019.

UNITED NATIONS HUMAN SETTLEMENTS PROGRAMME (UN-HABITAT). International guidelines on urban and territorial planning. Nairobi: UN-HABITAT, 2015.

UNITED NATIONS HUMAN SETTLEMENTS PROGRAMME (UNHABITAT). SDG GOAL 11 Monitoring Framework: A guide to assist national and local governments to monitor and report on SDG Goal 11 indicators. Nairobi: UN-HABITAT, 2016.

UNITED NATIONS HUMAN SETTLEMENTS PROGRAMME (UNHABITAT). Streets as public spaces and drivers of urban prosperity. Nairobi: UN-HABITAT, 2013.

UNITED NATIONS HUMAN SETTLEMENTS PROGRAMME (UN-HABITAT). Sustainable urbanization in the Paris Agreement: Comparative review of Nationally Determined Contributions for urban content. Nairobi: UN HABITAT, 2017. 
UNITED NATIONS POPULATION FUND (UNFPA). Sustainable Development and Population Dynamics: Placing people at the center. 2013. Available at: http://www.unfpa.org/press/sustainable-developmentand-population-dynamics-placing-people-centre. Accessed on: 15 May 2019.

UNITED NATIONS HUMAN SETTLEMENTS PROGRAMME (UNHABITAT). Sustainable Development and Population Dynamics: Placing people at the center. 2013. Available at: http://www.unfpa.org/ press/sustainable-development-and-population-dynamics-placing-peoplecentre. Accessed on: 15 May 2019.

VIVEKANADA, J. Climate and security in urban Spaces and the role migration plays. Available at: http://www.transre.org/en/blog/climateand-security-urban-spaces-migration/. Accessed on: 15 Mar. 2019.

WARN, E.; ADAMO, S. B. The impact of climate change: migration and cities in South America. World Meteorological Organization (WTO), [S.l.], v. 63, n. 2, 2014.

WATERS, C. N.; ZALASIEWICZ, J. A.; WILLIAMS, M. An introduction to the Anthropocene: case for and against a new epoch. In: WATERS, C. N.; ZALASIEWICZ, J. A.; WILLIAMS, M. A Stratigraphical Basis for the Anthropocene. London, UK: Geological Society of London Special Publications, 2014.

XXV PRÊMIO JOVEM CIENTISTA. Impactos das mudanças climáticas nas cidades: Capítulo 7 - Caderno do Professor, 2019, p. 7. Available at: http://www.seduc.go.gov.br/intranet/portal/sistemas/not/ files/... Accessed on: 5 May 2019. 


\section{Diogo Andreola Serraglio}

E-mail: diogo.aserraglio@gmail.com

Pós-Doutorando no Deutsches Institut für Entwicklungspolitik (DIE). Doutor e Mestre em Direito pela Pontifícia Universidade Católica do Paraná (PUCPR). Membro da Comissão Mundial de Direito Ambiental da International Union for Conservation of Nature (IUCN) e da Rede Sul Americana para as Migrações Ambientais (RESAMA).

Endereço profissional: Tulpenfeld 06, 53113 Bonn, Alemanha.

\section{Heline Sivini Ferreira}

E-mail: hsivini@yahoo.com.br

https://orcid.org/0000-0001-8736-8147

Doutora e Mestre em Direito pela Universidade Federal de Santa Catarina (UFSC). Professora Adjunta do Curso de Graduação e do Programa de PósGraduação em Direito da Pontifícia Universidade Católica do Paraná (PUCPR). Coordenadora Regional da Associação dos Professores de Direito Ambiental do Brasil (APRODAB-Sul). Membro da Comissão Mundial de Direito Ambiental da International Union for Conservation of Nature (IUCN).

Endereço profissional: Rua Imaculada Conceição, n. 1.155, Prado Velho, Curitiba, PR. CEP: 80.215-901.

\section{Nicholas A. Robinson}

E-mail: nrobinson@law.pace.edu

Doutor em Direito pela Columbia University School of Law. Professor Emérito da Elisabeth Haub School of Law da Pace University. Presidente-fundador da International Union for Conservation of Nature e participou dos trabalhos preparatórios que resultaram na Conferência das Nações Unidas sobre o Meio Ambiente e Desenvolvimento de 1992 e na Agenda 21.

Endereço profissional: 78 North Broadway, White Plains, NY, 10603, EUA. 